NASA Technical Memorandum 89860

AIAA-87-0994

\title{
Resistojet Control and Power for High Frequency ac Buses
}

\author{
(NASA-TH-89860) \\ ECHER FCF HIGH FESISTCJET CCATECL AND \\ $33 \mathrm{p}$ \\ (NASA) \\ CSCL 09C
}

N87-20477

\section{$63 / 33 \quad \begin{array}{ll}\text { Unclas } \\ 45425\end{array}$}

Robert P. Gruber

Lewis Research Center

Cleveland, Ohio

Prepared for the

19th International Electric Propulsion Conference cosponsored by the AIAA, DGLR, and JSASS

Colorado Springs, Colorado, May 11-13, 1987 


\title{
RESISTOJET CONTROL AND POWER FOR HIGH FREQUENCY AC BUSES
}

\author{
Robert P. Gruber \\ National Aeronautics and Space Administration \\ Lewis Research Center \\ Cleveland, Ohio 44135
}

\begin{abstract}
SUMMARY
Resistojets are operational on many geosynchronous communication sate111tes which all use dc power buses. Multipropellant resistojets were selected for the Initial Operating Capability (IOC) Space Station which will supply $208 \mathrm{~V}, 20 \mathrm{kHz}$ power. This paper discusses resistojet heater temperature controllers and passive power regulation methods for ac power systems. A simple passive power regulation method suitable for use with regulated sinusoidal or square wave power was designed and tested using the Space Station multiprope1lant resistojet. The breadboard delivered $20 \mathrm{kHz}$ power to the resistojet heater. Cold start surge current limiting, a power efficlency of 95 percent, and power regulation of better than 2 percent were demonstrated with a two component, $500 \mathrm{~W}$ breadboard power controller having a mass of $0.6 \mathrm{~kg}$.
\end{abstract}

\section{INTRODUCTION}

Resistojets are conceptually simple. The propellant is heated by convection, conduction, and/or radiation from a resistively heated element and then expanded through a nozzle to produce thrust. Resistojets were flight tested as early as 1965 (ref. 1).

NASA and others are developing multipropellant resistojet technology for the initial operating capability (IOC) Space Station and high performance resistojet concepts for spacecraft applications (refs. 2 to 12). Figure 1 is a photograph of the multipropellant resistojet engineering model and figure 2 is a cross-sectional sketch of this resistojet with the major features identified. The design choices, features, and construction detalis are reported elsewhere (ref. 3). The multipropellant resistojet must be integrated with the Space Station power system (ref. 13) which will be a $20 \mathrm{kHz}, 208 \mathrm{~V}$, single phase sinusoidal voltage bus.

The purpose of this paper is to present power bus integration considerations, design approaches, and performance characteristics for simple, passive, high efficiency, and lightweight power regulators for multipropellant resistojets operating from regulated ac power buses.

Basic design equations were derived describing power circuits which passively control resistojet heater power under conditions of varying heater resistance. Several candidate circuits were examined, some of which were suitable not only for regulated sinusoidal voltage buses, but regulated square wave voltage as well. A simple passive heater controller and cold start surge current limiter breadboard was built and tested with the engineering model resistojet. Tests results are compared with the design equations. 


\section{NOMENCLATURE}

a dimensiontess variable

$a_{0}$ value of dimensionless variable that maximizes power, 3.212

A leakage inductance referred to transformer secondary index for a given transformer core and winding geometry; $\mathrm{H} / \mathrm{turn}^{2}$

$A_{C}$ effective cross-sectional area of a given transformer core, $\mathrm{cm}^{2}$

$B_{\max }$ maximum flux density of transformer core, $G$

C capacitance, $F$

f frequency, $\mathrm{Hz}$

1 instantaneous load current, A

I load current, A rms

$L$ total inductance in secondary circutt, $H$

$L_{\ell} \quad$ leakage inductance, $H$

n secondary to primary transformer turns ratio

$N_{s}$ transformer secondary turns

p.f. load power factor at the bus

P load power, $W$

$P_{N} \quad$ normalized load power; load power divided by load power at $R_{0}$

R load resistance, $\Omega$

$R_{0} \quad$ load resistance that maximizes load power unless maximum $=\infty$, then $R_{0}=1, \Omega$

$R_{N}$ normalized load resistance, $R$ divided by $R_{0}$

$t \quad$ time, sec

$T$ period, sec

$v \quad$ instantaneous secondary open circuit voltage, $v$

$v$ load voltage, $v$ rms

$V_{\text {in }}$ input voltage from bus, $V$ rms

$V_{\text {oc }}$ open circuit transformer voltage, $v$ rms

$X_{C} \quad$ capacitive reactance, $\Omega$ 
$X_{L} \quad$ inductive reactance, $\Omega$
$Z$ impedance, $\Omega$

REQUIREMENTS

Spacecraft Considerations

The Space Station power distribution is regulated $20 \mathrm{kHz}$ ac. A preliminary description of the Space Station power bus is given in table I (ref. 14). At this writing, more detailed specifications are being developed. The Space Station voltage is sinusoidal and closely voltage regulated. A few spacecraft have used square wave power buses. For example, the Mars Viking Orbiter had a relatively low power $(\sim 350 \mathrm{~W})$ bus that used voltage regulated $2.4 \mathrm{kHz}$ square waves (ref. 15). With regulated ac voltage, either sine wave or squarewave, a new set of passive and active resistojet control techniques becomes attractive.

Since detalled power system specifications were not available at this writing, it is necessary to speculate about some of the technical issues that could impact other Space Station systems. The first major issue would be user power profile. The power for each resistojet is only $500 \mathrm{~W}$ compared to the spacecraft nominal system power of about $75 \mathrm{~kW}$. Therefore, cold start surge current and initial low power factor may not be serious concerns. A method of power control that results in a train of power pulses, a few seconds in length (depending upon the heater time constant), to provide for an average power need of less than $500 \mathrm{~W}$ has been suggested (ref. 16). Thus the bus would be pulse loaded, but at low power. Since this has significant system advantages, the power bus may be able to accommodate this regulation technique.

Another issue that could impact the bus is surge current that can be caused by transformer core remnant magnetization. Under conditions when the initial applied voltage causes the core flux to increase in the same direction as that of the remnant magnetization, the core saturates. The resulting steep increase in magnetizing current causes a short duration (of order $10 \mu \mathrm{sec}$ ), high amplitude current surge resulting in temporary voltage distortion. This uncertain, high intensity short duration surge is markedly different from the cold start surge current due to low heater resistance.

At $20 \mathrm{kHz}$, magnetic field electromagnetic compatibility requirements may become significant. The system Requirements and Interface Definition Study (ref. 4) reports that a preliminary analysis was conducted to estimate the level of electro-magnetic interference (EMI) generated within the resistojet. A heater wire loop near the nozzle contains $25 \mathrm{~mm}$ ( $1 \mathrm{in.)}$ of wire without current in an adjacent wire in the opposite direction. A worst case estimate of the magnetic induction was about $102 \mathrm{~dB}$ above 1 pT which exceeds the MIL-STD $461 \mathrm{~B}$ specification. The effect of the resistojet thermal insulation and outer case, and the distance from the resistojets to sensitive equipment must be determined. The report also states that if the magnetic induction is found to exceed actual requirements for user experiments, possible solutions include the following: (1) shield the resistojets with iron, (2) shield the experiments, (3) use a dc power supply, (4) devise a heater coll with no uncompensated length. Another potential technique to reduce radiated EMI is to take advantage of the fact that the thruster heater terminating leads also enclose an area that radiates a magnetic field. If the leads could be arranged so that 
they enclose an equal area and that the current flows in the opposite direction, then this would help reduce the magnetic field at distances much greater than thruster length. The power controller may require one or more iron foil or thin walled case shields to meet the finalized spacecraft electromagnetic compatibility specification.

\section{Thruster System Considerations}

Preliminary resistojet control and power requirements for Space Station auxiliary propulsion and waste fluid management were described in a system requirement and interface definition study (ref. 4) for the Space Station engineering model resistojet (ref. 3). Key resistojet system control requirements were to limit heater temperature to $1400{ }^{\circ} \mathrm{C}$ with most propellants to ensure long life; and to assure that heater temperatures are less than $500{ }^{\circ} \mathrm{C}$ when using methane so free carbon is not produced; and to accommodate variable composition gases. The referenced study compared four heater control methods which were: (1) constant power and fixed inlet pressure (outlet gas temperature will vary, with specific impulse degrading for off nominal gas composition); (2) constant inlet pressure and variable power (the heater can be maintained near $1400^{\circ} \mathrm{C}$ for maximum specific impulse); (3) constant inlet pressure and two power settings; (most gases could be used at the high power level, mixtures containing methane or cabin air are used with the lower power level) and (4) constant power and variable flow control (heater temperature can be maintained near $1400^{\circ} \mathrm{C}$ for maximum specific impulse). The four control methods were compared and the results presented in table II.

The tentative selection of the control power method was based on the desire for simplicity while sufficiently heating the propellants to provide about twice the room temperature specific impulse and to avoid condensation. The method uses constant inlet pressure with two power settings. Since the efforts reported in this paper are concerned primarily with heater control, it is noted that three of the four control methods studied required maintaining constant heater power. The fourth method requires constant heater temperature control. Heater control techniques for power and temperature will be discussed in detall later in the paper. An additional power control function may be required. As a precaution, to account for the condition of propellant flow interruption, a means of sensing heater over temperature and reducing power may be necessary.

At the $20 \mathrm{kHz}$ bus frequency, thruster system skin and proximity effects should be taken into consideration, if ac is used for heater power. Handbook (ref. 17) calculations for the resistojet cold heater resistance show an increase of resistance of about 0.1 percent, considering only skin effects for the $1.52 \mathrm{~mm}$ ( $0.060 \mathrm{in.)}$ diameter platinum - 10 percent rhodium heater element. The proximity effect of opposite direction currents in the adjacent heater windings is more difficult to determine since the calculated skin depth is large, $1.55 \mathrm{~mm}(0.061 \mathrm{in.})$ compared to the heater wire diameter and the interaxial heater wire separation of $3.15 \mathrm{~mm}(0.125 \mathrm{in.})$. However, the increase in resistance due to proximity effect will be less than 15 percent according to handbook information (ref. 17).

High performance hydrazine resistojet thrusters (ref. 10) used in geosynchronous communication satellites have tungsten heaters that exhibit hot to cold resistance changes of more than 10:1. The hydrazine resistojet systems 
incorporate cold start surge current limiting (refs. 10 and 11). The long life, multipropellant resistojet, which uses a platinum-10 percent rhodium heater exhibits a $25{ }^{\circ} \mathrm{C}$ to $1400{ }^{\circ} \mathrm{C}$ heater resistance change of about $3: 1$. It has not yet been established whether the Space Station resistojet itself requires cold start surge current limiting to ensure reliable operation. The issues could be potential risk of excess mechanical fatigue and contact resistance degradation due to the many on-off cycles expected over the life of the resistojet. Surge current and power limiting both ease the impact of these concerns and make the thruster system a more friendly bus user.

Since the heater operates at low maximum voltages (20 to $30 \mathrm{~V}$ ), a device (e.g., transformer or ac to dc regulator) must be used to match the heater to the high voltage (208 V) bus.

\section{DESIGN}

\section{Design Philosophy}

The design objective was to demonstrate a control and power electronics concept specifically for the Space Station resistojet used in conjunction with the $20 \mathrm{kHz}$ sinusoidal power bus. However, the results are applicable to power buses other than space Station. Therefore, the suitability of the control scheme developed when used with a square wave bus voltage was also investigated and discussed in appendix $A$.

of paramount importance to Space Station propulsion systems are 11fe, low maintenance, and simplicity. The space Station multipropellant resistojet was designed for lifetimes in excess of $10000 \mathrm{hr}$ with less emphas is on high performance. In concert with this philosophy, the resistojet power controller concept should be simple and capable of long life. Furthermore, the design approach should provide adequate thruster system performance, high power efficlency, and light weight.

The first issue is whether to power the resistojet heater with ac or $d c$. Using dc alleviates the question of thruster magnetic fleld radiation; the need to incorporate coaxial or special high current, high frequency transmission 1 ines and connectors; and can result in uncomplicated resistance measurement circuits. However, changing the available, regulated ac power into dc power reduces power efficiency, requires semiconductors, and complicates the power train circuitry. Since the power bus detalled specifications and sub system constraints are not yet completed at this writing, and since the control scheme for the resistojet has not yet been finalized, resistojet heater power was chosen to be ac for purposes of concept demonstration.

The next major issue considered is the method of control. For the work described here, heater control will be considered only for ac heater power. of the four control options discussed earlier (ref. 4), three rely on constant power control while one maintains constant heater temperature using variable power. One technique for maintaining constant heater temperature is to determine and control the average heater resistance by varying heater power. This technique has been used as a maximum temperature 1 imiter for high performance hydrazine electrothermal thrusters (ref. 18). The circuit was needed to prevent overtemperatures due to momentary propellant loss or low pressure near end of life when propellant flow would be low. The thruster heater formed one leg 
of a resistance bridge that was supplied power through a series pass transistor. A control circuit maintained constant resistance by varying the current through the series pass transistor to keep the bridge balanced. Another control method, developed in Germany, that senses thruster temperature directly and controls the thruster using a microprocessor, has been designed, bullt and tested (ref. 9).

The writer has developed and tested closed loop resistance controllers using power dissipative and nondissipative techniques. The controllers operated from $d c$ power sources and measured resistance from heater voltage and current signals. Some of the circuits were used in thruster characterization tests (ref. 19). Measuring and accurately controlling resistance from ac heater signals is much more difficult than with dc heater signals. For ac, heater inductance as well as skin and proximity effects must be considered in the design. If dc analog control circuits are used, the ac signals must be converted accurately to dc. Once suitable resistance determining signals are avallable, ac closed loop control techniques can be implemented.

For ac constant heater temperature control systems, the series pass control element can be a high power efficiency direct current controlled reactor (ref. 20) or a variable leakage inductance transformer (VLT) (ref. 21) instead of a semiconductor. These magnetic components can be rugged and reliable; however, the VLT is a fairly complex magnetic component. Direct current controlled reactors and VLT's are nonlinear and will create nonsinusoidal currents. These devices must be designed so that harmonic currents drawn from the bus are within bus specifications.

The effort described in this paper will concentrate on constant power control instead of resistance control. Constant power control provides an opportunity to achieve simplicity and was the preliminary thruster system heater control method selected as well as being employed in three of the four control methods discussed earlier (ref. 4). In keeping with the desire for thruster system simplicity and high reliability, a passive regulation scheme was designed, built, and tested.

\section{Design Approach}

The resistojet heater power and control concept is simply a current 1 imiting transformer. This current limiting technique has been used for lighting applications and filament heating. The equivalent circuit for the transformer used in this work reduces to a voltage source driving an inductor in series with the variable resistance thruster heater. This simple equivalent circuit can be used for this particular current limiting transformer since the secondary open circuit inductive reactance is large compared to transformer leakage inductive reactance referred to the secondary and thruster heater resistance is large compared to the transformer winding resistance. The fundamental equations governing this power regulating method are listed in appendix $B$.

Figure 3 shows the transformer output characteristic. The transformer can also supply almost constant power over a wide range of resistances as seen in figure 3 when a constant power hyperbola is superimposed on the transformer output characteristic. Figure 3 also shows how the cold start surge current is iimited. This power regulation technique is shown in figure 4 together with normalized power variations for current or voltage regulation versus normalized 
resistance. The graph shows that power regulation of 0 to 5 percent is possible for nearly a $2: 1$ change in resistance. The technique has the potential disadvantage of low power factor ( 0.7 at maximum power), but at high frequencies $(20 \mathrm{KHz})$, a high degree of passive power factor correction can easily be provided for almost no penalty.

Simple passive power factor correction at the power bus can be achieved for steady-state operation by using a shunt capacitor as shown in figure 5(a). With respect to the bus voltage, the lagging current in the current limiting transformer is added to the leading current in the capacitor. The resultant bus current is corrected for the transformer load power factor at one value of heater resistance as defined in equation (B11). The total load power factor wlll be leading or lagging depending upon the heater resistance. Power factor will vary according to equation (B10). The corrected power factor is nearly 1.0 for the range of heater resistances necessary for steady-state operation.

The change in power due to bus voltage regulation tolerance can be approximated using the total differential of power.

$$
\frac{d P}{P}=\left(\frac{\partial P}{\partial V_{i n}}\right) d V_{i n}+\left(\frac{\partial P}{\partial R}\right) d R
$$

For the constant power scheme described by equation (B5) in appendix B,

$$
\frac{d P}{P}=\frac{2 d V_{\text {in }}}{V_{\text {in }}}+\left(\frac{x_{L}^{2}-R^{2}}{x_{L}^{2}+R^{2}}\right) \frac{d R}{R}
$$

For conditions of nearly constant power, heater operation is near the maximum power point where $R$ nearly equals $\left|X_{L}\right|$, so the second term in equation (2) is nearly zero during steady-state heater operation. Therefore,

$$
\frac{d P}{P} \simeq \frac{2 d V_{\text {in }}}{V_{\text {in }}}
$$

and the 2.5 percent bus voltage regulation results in a heater power variation of about 5 percent.

Figure 5 shows several variations in implementation of the basic power control scheme. Table III compares the major advantages and disadvantages of each method. Multiple power setpoints can be provided using transformer tap changes, figure 5(b) or duty ratio pulsing, figure 5(c). A separate inductor in the primary figure $5(d)$ could be used to reduce initial current surges if remnant magnetization of the transformer core causes an unacceptable short duration initial current surge. Other means to reduce or eliminate the potential current surge due to remnant magnetization should the bus requirements dictate, include designing for a lower maximum flux density (higher weight); not choosing a square hysteresis loop magnetic material; making circuit provisions to set the core at a known flux direction and value; or using cores with a small gap.

The passive method of using a series capacitor and thruster resistance matching transformer figure $5(\mathrm{e})$, would result in the same current limiting 
characteristic as the series inductor for sinusoidal waveforms, capacitive reactance current limiting is similar to inductive reactance current limiting and fundamental circuit considerations show that maximum power transfer occurs when the load resistance is equal to $n^{2}\left|x_{c}\right|$.

However, the power factor would be leading and difficult to correct since a shunt inductor is needed. At least two components would be needed instead of just one, but the method will have slightly less weight and silightly higher efficiency. Furthermore, if two thrusters need to be fired simultaneousiy, (such as opposing thrust waste fluid disposal), then the scheme in figure $5(e)$ could be paralleled with the method shown in figure 5(a) to provide a scheme, figure 5(f), that will maintain bus load power factor at nearly 1.0 during start up as well as steady-state operation. The capacitive reactance method was not evaluated further as part of this reported work.

\section{Design Detałls}

The scheme shown in figure 5(a) was designed, built, and tested with a thruster. The basic transformer technology was developed under the NASA Lewis Research Center power magnetics program (refs. 22 and 23). The 25 KVA transformer developed under this program featured a simple, reliable, and effective thermal control system. Furthermore, the $20 \mathrm{kHz}$ transformer was 1ightweight and efficient. The basic mechanical configuration lended itseif well to breadboard construction because no unusual fabrication techniques were necessary. Also, as part of the power magnetics program, transformer mass equations were derived from fundamentais. The equations were used to graph normalized specific weight versus magnetic flux density, power, and frequency. The graph is useful for resistojet system transformer mass predictions.

The $25 \mathrm{KVA}, 20 \mathrm{kHz}$ transformer developed under the power magnetics program was designed for low leakage inductance. The transformer used for this work requires a much higher leakage inductance for constant power and load current limiting characteristics. Developing accurate analytical expressions for leakage inductance based on the core and winding geometry was not practical because, for this transformer, leakage inductance calculations must take into account varying winding geometries as well as magnetic flux paths with changing flux densities (ref. 24). Therefore, an approximate expression developed for leakage inductance that incorporates an empirically determined constant, A:

$$
L_{\ell} \cong A N_{S}^{2}
$$

A 10 turn trial winding was used together with a shorted turn primary (copper foll). Using equation (4) measurements of $L_{\ell}$ provided values of A for a variety of magnetic cores and winding arrangements.

The transformer equation (ref. 25) provides another design equation:

$$
N_{s}=\frac{n V_{\text {in }}}{4.44 \times 10^{-8} A_{c} B_{\text {max }} f}
$$

For this transformer, equations (4) and (5) combine to constrain the number of turns according to: 


$$
N_{S}=4.44 \times 10^{-8} \frac{\mathrm{fL}_{\ell} B_{\max }}{n V_{\text {in }}} \frac{A_{c}}{A}
$$

The resistance value for maximum heater power was chosen using figure 4 together with the expected steady-state thruster heater resistance variations for the range of propellants at the pressure used. Once the value of thruster resistance required for maximum power was determined, the bus voltage, and equations (B5), (B8), and (B9), were used to obtain values for the turns ratio, $n$ and the total inductance, $L$.

The total inductance, $L$ necessary was $6.0 \mu \mathrm{H}$. The leakage inductance required was reduced by the heater and heater connecting wire inductances which totaled $1.6 \mu \mathrm{H}$, so only $4.4 \mu \mathrm{H}$, was needed for the leakage inductance, $L_{\ell}$. The transformer core was selected using trial designs together with a selection of conveniently avallable magnetic cores, so that the transformer flux density was not near the saturation flux density, which was about $7 \mathrm{~kg} . A_{C}$ and $A$ were adjusted to achieve a convenient $N_{s}$ for a wire size and magnetic core that resulted in modest power 10s5. An adequate value of leakage inductance was easy to achieve for the $20 \mathrm{kHz}$ current limiting transformer. The final flux density and all the transformer parameters are listed in table II. The mechanical construction details are shown in figure 6 . No attempt was made to minimize the transformer mass or optimize its efficiency.

If the highest power efficiency or lightest weight becomes necessary instead of minimum parts count, then a separate inductor or capacitor in series with the transformer primary as shown in figures $5(d)$ and (e) should be considered.

Power factor correction to 1.0 was arbitrarily chosen at the maximum power point. The required value of capacitance was calculated using equations (B11) and (B12). The actual capacitor used was a standard value $0.10 \pm 0.01 \mu \mathrm{F}$ fo11polypropelene dielectric capacitor rated by the manufacturer at $400 \mathrm{Vrms,}$ 7 Arms. The cylindrical capacitor measured $1.43 \mathrm{~cm}(0.562 \mathrm{in.})$ diameter by $3.49 \mathrm{~cm}(1.375 \mathrm{in.})$ long and had a mass of $15 \mathrm{~g}$. Equivalent series resistance (ESR) was not specified or measured, but the capacitor remained cool to the touch during tests at $208 \mathrm{~V}, 20 \mathrm{kHz}$.

\section{TESTS}

\section{Loadbank Tests}

A resistive load was used to determine power efficiency, transformer temperature rise, and to verify power factor correction and the transformer load characteristic. The power controller was tested at $208 \mathrm{rms}, 20 \mathrm{kHz}$ input power using several $0.10 \Omega$ "noninductive" resistors in series. The inductance of the resistor network approximated the thruster and thruster lead inductance $(1.6 \mu \mathrm{H})$ only at a load value of $0.7 \Omega$. For lower resistance values, extra inductance was added to total $\sim 1.6 \mu \mathrm{H}$. Higher values of resistance had inductance values above $1.6 \mu \mathrm{H}$, yet adequate for load characteristic verification. For future tests, it may be easier to use a carbon pile load to keep the lead geometry and, therefore, the inductance approximately constant. For all tests reported, except the temperature rise test, a small fan was used to cool the transformer. 
Measurements were made using three RMS voltmeters with analog readouts which had full scale accuracies of \pm 1 percent. Input and output voltages were measured directly. Output current was measured using a current transformer. A phasemeter measured the phase lag between the output current and the output voltage (at the transformer terminals). Power quality was checked using an oscilloscope. The input voltage was smoothly varying and almost sinusoidal. Real input power was measured using the $20 \mathrm{kHz}$ generator power meter which was checked at $400 \mathrm{~W}$ using a "noninductive" resistor. The phasemeter input was voltage limited to $20 \mathrm{~V}$. Special voltage dividers necessary to measure the input voltage phase relationship to transformer currents were not available so power factor correction was verified using an oscilloscope.

At an input of $208 \mathrm{~V}$, with a $0.7 \Omega, 1.6 \mu \mathrm{H}$ load the following measurements were made: real input power, $542 \mathrm{~W}$, output voltage, $20.05 \mathrm{~V}$; output current, $26.9 \mathrm{~A}$; phase between the output current and voltage, $16^{\circ}$. The real power out, calculated from the voltage, current and phase measurements was approximately $518 \mathrm{~W}$ which implies a power efficiency of about 95 percent.

The center heat sink temperature just below the windings was measured with a thermocouple. Steady-state temperature rise was measured for natural convection, with the transformer supported on an insulated benchtop. The test data are summarized in table IV.

\section{Thruster Tests}

The power controller was tested with the multipropellant resistojet mounted in a vacuum facility. The same electrical instrumentation that was used for the loadbank tests was used for thruster tests. The test configuration is shown in figure 7 . Electrical data were recorded manually as well as with a slow $(180 \mathrm{~mm} / \mathrm{hr})$ chart recorder. The thruster was instrumented with several thermocouples for other tests (ref. 5), so temperatures were also recorded. Tests were run at constant inlet pressure with helium, carbon dioxide, and argon, to span a range of propellant heat capacities which resulted in a corresponding range of resistances. For each gas, the thruster was started at room temperature and run until steady state was reached. Propellant line pressure, for each propellant, increased about $4.8 \mathrm{~N} / \mathrm{cm}^{2}$ ( 7 psia) as the thruster heated. Transient thruster data for argon and helium propellants are presented in figures 8 and 9 respectively. Heater power, current, resistance and heater sheath temperature are plotted as functions of time. Using this startup technique operating power was achieved in about 7 min. The thruster reached 90 percent of maximum resistance and heater temperature in about $20 \mathrm{~min}$.

The power controller load characteristic at the thruster heater was calculated using equations from appendix $B$ which required values of the measured secondary leakage inductance, thruster and connecting wire inductance, and open circuit voltage. The calculation neglects transformer winding resistances including skin and proximity effects. The calculated load characteristics and a $500 \mathrm{~W}$ constant power curve are plotted in figure 10 together with thruster test data and loadbank data. Loadbank data verify the transformer functional characteristics. Thruster data for steady-state operations as well as startup demonstrate surge current limiting and constant power operation. 
Initial measured output power varied from 425 to $446 \mathrm{~W}$. Calculated initial power output was about $404 \mathrm{~W}$. The initial power was calculated for room temperature measured dc resistance $(0.345 \Omega)$ at the transformer secondary terminals. Accurate initial measurements were difficult since the heater resistance was changing rapidly and the power source voltage was drifting after initial turn on. The heater sheath temperature was measured on the last heater coll at the nozzle end. Steady-state test data for all propellants tested are listed in table V. Steady-state data for argon and hellum are also available from figures 8 and 9 . Power regulation is about 2 percent over the resistance range of 0.7 to $0.9 \Omega$ heater resistance. Measured heater sheath temperature was $650^{\circ}$ for helium and $1020^{\circ} \mathrm{C}$ for argon. Heater steady-state temperature versus power data agree closely with dc power and temperature data from other tests (ref. 5).

\section{DESIGN CONSIDERATIONS FOR AN ENGINEERING MODEL CONTROLLER}

Further development effort should awalt more detalled power bus specifications as we 11 as thruster system requirements. Radiated magnetic field restrictions will impact the controller mechanical and thermal designs. If the restrictions are quite severe, the magnetic component designs could change. A current limiting transformer with its greater leakage flux than conventional transformers may have to be replaced with a low flux leakage conventional transformer and separate current limiting capacitor or inductor in the primary circuit.

Based on tests with the unoptimized power controller, it is judged that passive power control meeting typical spacecraft thermal, EMI, and vibration specifications can be accomplished at power efficiencies of at least 97 percent and packaged mass of less than $2 \mathrm{~kg}$ for each 500-W thruster. Power regulation tolerance will equal twice the bus voltage tolerance (the bus voltage tolerance is \pm 2.5 percent at this writing) plus 2 or 3 percent due to the passive power controller characteristics.

There may be a need for an excessive temperature indication should propellant flow be interrupted. A single overtemperature indication signal can be obtained, if necessary, by adding a signal level winding near the secondary or by simply measuring the secondary voltage (the thruster heater is isolated from spacecraft structure). Since the transformer characteristic is fixed, the voltage is a function of heater resistance which in turn is a function of average heater temperature. This overtemperature indication method assumes adequate input bus voltage regulation. Bus transients and drop-outs can be easily accommodated with signal level components.

\section{CONCLUSIONS}

A simple, passive resistojet power controller was designed and tested to Space Station power bus specifications. The power controller delivered $20 \mathrm{kHz}$ power to the Space Station multipropellant resistojet heater using a $208 \mathrm{~V}$, $20 \mathrm{kHz}$ sinusoidal power source. The thruster was operated at constant in let pressure and constant power using helium, carbon dioxide and argon. Steady state thruster heater resistance ranged from 0.7 to $0.9 \Omega$ for the three propellants used. Cold start surge current limiting, a power efficiency of 95 percent, and power regulation of better than 2 percent were demonstrated 
with a two component, 500-W breadboard power controller having a mass of $0.6 \mathrm{~kg}$.

Based on the breadboard tests, it is judged that a passive engineering model power controller meeting typical spacecraft thermal, EMI and vibration specifications can be developed having power efficiencies in excess of 97 percent and a packaged mass of less than $2 \mathrm{~kg}$. for each $500-W$ Thruster. 


\section{APPENDIX A - EQUATIONS FOR A SQUARE WAVE VOLTAGE SOURCE}

The purpose of this appendix is to determine the operating characteristics of the power controller for the special case where thruster systems are powered from a square wave voltage source.

When a current limiting transformer is used to supply the thruster heater, the equivalent circult of the thruster system reduces to a square wave voltage source (transformer secondary open circuit voltage in series with the variable heater resistance, the heater and power cable inductance, and the transformer leakage inductance referred to the secondary).

The differential equation for a voltage source in series with a resistor and inductor is:

$$
v(t)=L \frac{d i}{d t}+1 R
$$

Solving the differential equation for steady-state operation with a square wave voltage source over the haif cycle when the voltage is positive yields:

$$
i(t)=\frac{V_{O C}}{R}\left[1-\frac{2 e^{-t R / L}}{\left(1+e^{-a}\right)}\right] \text { for } 0<t<\frac{T}{2}
$$

where

$$
a=\frac{R}{2 f L}
$$

is used for conventence.

The average power is found from

$$
P=\frac{2 R}{T} \int_{0}^{T / 2} i^{2}(t) d t
$$

This results in

$$
P=\frac{V_{o c}{ }^{2} T}{2 L}\left[\frac{1}{a}-\frac{2}{a^{2}}\left(\frac{1-e^{-a}}{1+e^{-a}}\right)\right]
$$

An expression for maximum power is found by setting the first derivative of power with respect to a equal to zero and obtaining the roots of

$$
\frac{1}{a^{2}}\left[\frac{4}{a}\left(\frac{1-e^{-a}}{1+e^{-a}}\right)-\frac{4 e^{-a}}{\left(1+e^{-a}\right)^{2}}-1\right]=0
$$

Since equation (A6) cannot be solved in closed form, an iterative solution such as the Newton Raphson Method (ref. 26) must be used to obtain the root 


$$
a_{0}=3.212
$$

and from equation (A3)

$$
R_{0}=2 \times 3.212 \mathrm{fL}
$$

An expression for normalized power, as a function of normalized resistance was obtained by substituting

$$
a=R_{N} a_{0}
$$

Then

$$
P_{N}=\frac{\left[\frac{1}{R_{N} a_{0}}-\left(\frac{2}{R_{N}^{2} a_{0}^{2}}\right)\left(\frac{1-e^{-R_{N} a_{0}}}{1+e^{-R_{N} a_{0}}}\right)\right]}{\left[\frac{1}{a_{0}}-\frac{2}{a_{0}}\left(\frac{1-e^{-a_{0}}}{1+e^{-a_{0}}}\right)\right]}
$$

When graphed, equation (A10) shows that the curve for square wave normalized power follows the curve for normalized sinusoidal power in figure 4 within 2 percent. Furthermore the equations defining $R_{0}$ for square waves and $R_{0}$ for sinusoidal power differ only by a constant. The slight difference is that for square waves the constant is 3.212 , while the constant for sine waves is $\pi$.

of course simple shunt capacitance power factor correction cannot be used for square wave voltage power buses. 
The fundamental equations governing the power regulating method are 1isted in this appendix. The equations are basic and describe a sinusoidal voltage source driving a series inductance resistance load. They are:

$$
\begin{aligned}
& V_{\text {OC }}=n V_{\text {in }} \\
& |I|=\frac{V_{O C}}{|Z|} \\
& V=V_{\text {OC }} \frac{R}{|Z|}
\end{aligned}
$$

where

$$
|z|=\sqrt{x_{L}^{2}+R^{2}}
$$

from which

$$
P=n^{2} v_{\text {in }}^{2} \frac{R}{\left(x_{L}^{2}+R^{2}\right)}
$$

and

$$
P_{N}=\frac{2 R_{N}}{R_{N}^{2}+1}
$$

where

$$
R_{N}=\frac{R}{R_{0}}
$$

and

$$
R_{0}=\left|X_{L}\right|
$$

$$
\left|X_{L}\right|=2 \pi f L
$$

Adding a shunt capacitor across the reflected series resistance-inductance load at the power bus will modify the power factor according to:

$$
p . f .=\frac{R}{\sqrt{\frac{\left(\left|x_{L}\right|^{2}+R^{2}-n^{2}\left|x_{C}\right|\left|x_{L}\right|\right)^{2}}{n^{4}\left|x_{C}\right|^{2}}+R^{2}}}
$$

From equation (A10) the value of $X_{c}$ that will correct the load power factor to 1 at a specific value of heater resistance is:

$$
\left|x_{c}\right|=\frac{1}{n^{2}}\left(\left|x_{L}\right|+\frac{n^{2}}{\left|x_{L}\right|}\right)
$$

The capacitance value is obtained from:

$$
\left|x_{c}\right|=\frac{1}{2 \pi f L}
$$




\section{REFERENCES}

1. Mirtich, M.J., "Resistojet Propulsion for Large Spacecraft Systems," AIAA Paper 82-1948, Nov. 1982.

2. Jones, R.E., "High and Low-Thrust Propulsion Systems for the Space Station," AIAA 87-0398, Jan. 1987.

3. Pugmire, T.K., Cann, G.L., Heckert, B., and Sovey, J.S., "A 10,000 Hour Life Multipropellant Engine for Space Station Applications," AIAA Paper 86-1403, June 1986 .

4. Heckert, B.J., "Space Station Resistojet System Requirements and Interface Definition Study," RI/RD87-109, Rockwell International Corp., Canoga Park, CA, Feb. 1987. (NASA CR-179581).

5. Morren, W.E., Haag, T.W. and Sovey, J.S., "Engineering Model Resistojet Characterization," AIAA Paper 87-2120, May 1987.

6. Stone, J.R., "NASA Electrothermal Auxiliary Propulsion Technology," AIAA Paper 86-1703, June 1986.

7. McKevitt, F.X., "Design and Development Approach for the Augmented Catalytic Thruster (ACT)," AIAA Paper 83-1255, June 1983.

8. Dressler, G.A., Morningstar, R.E., Sackheim, R.L., Fritz, D.E. and Kelso, R., "Filight Qualification of The Augmented Electrothermal Hydrazine Thruster," AIAA Paper 81-1410, July 1981.

9. Schmitz, H.D. and Steenborg, M., "Augmented Electrothermal Hydrazine Thruster Development, "Journal of Spacecraft and Rockets, Vol. 20, No. 2, Mar.-Apr. 1983, pp. 178-181.

10. Feconda, R.T. and Weizman, J.I., "Satellite Reaction Control Subsystem with Augmented Catalytic Thrusters," AIAA Paper 84-1235, June 1984.

11. Bingley, J.D., "Cold Start Surge Current Limiting System for a Hydrazine Thruster Augmentation Heater," U. S. Patent 4,523,429, June 1985.

12. McKevitt, F.X. and Schwam, F.R., "Design, Performance, and Operational Scaling Criteria for Electricaliy Augmented Hydrazine Thrusters, "AIAA Paper 84-1234, June 1984.

13. Thomas, R.L., "Power is the Keystone," Aerospace America, Vo1. 24, No. 9, Sept. 1986, pp. 36-38,40.

14. Terdan, F.F., Private communication, NASA Lewis Research Center, Cleveland, $\mathrm{OH}$, Aug. 1986.

15. Decker, K., Private Communication, TRW Inc., Redondo Beach, CA, Mar. 1987.

16. Korn, I.I., Private communication, Rocketdyne Division of Rockwell International, Canoga Park, CA, Aug. 1986. 
17. Terman, F.E., Radio Engineers' Handbook, McGraw-H111, New York, 1943.

18. Hosick, D. and Rentella, W., Private communication, Ford Aerospace, Nov. 1984.

19. Morren, W.E., Whalen, M. and Sovey, J.S., "Performance and Endurance Tests of a Multipropellant Resistojet for Space Station Auxiliary Propulsion," AIAA Paper 86-1435, June 1986.

20. Aggers, C.V. and Pakala, W.E., "Direct-Current Controlled Reactors," Electric Journal, Vol. 34, No. 2, Feb. 1937, pp. 55-59.

21. Hirayama, H., "Simplifying Switched Mode Converter Design with a New Variable Leakage Transformer Topology," Proceedings of Powercon 7, R.I. Birdsal1, ed., Power Concepts Inc., Ventura, CA, 1980, Pp. E1-1 to E1-10.

22. Schwarze, G.E., "Development of High Frequency Low Weight Power Magnetics for Aerospace Power Systems," Advanced Energy Systems - Their Role In Our Future, Vol. 1, American Nuclear Society, LaGrange Park, IL, 1984, pp. 196-204.

23. Welsh, J.P., "Design and Development of Multi-kw Power Electronic Transformers," TTL-83-1, Thermal Technology Labs, Buffalo, NY, Feb. 1983. (NASA CR-168082).

24. Slemon, G.R., Magnetoelectric Devices, John Wiley \& Sons, New York, 1966.

25. Magnetic Circuits and Transformers, John Wiley \& Sons, New York, 1943.

26. Scarborough, J.B., Numerical Mathematical Analysis, Johns Hopkins Press, Baltimore, 1955. 
TABLE I. - PROVISIONAL SPACE STATION POWER BUS DESCRIPTION (ref. 14)

[August 1986.]

\begin{tabular}{|c|c|c|}
\hline Item & Description & Comments \\
\hline Nominal system power & $75 \mathrm{~kW}$ & \\
\hline Frequency & $20 \mathrm{kHz} \pm 0.1$ percent & Sinusiodal waveform \\
\hline Voltage & $208 \mathrm{~V}$ rms \pm 2.5 percent & At user loads \\
\hline Power factor & 0.9 Minimum lagging & $\begin{array}{l}\text { Specified for entire power } \\
\text { system }\end{array}$ \\
\hline $\begin{array}{l}\text { Total harmonic } \\
\text { distortion }\end{array}$ & 3 percent & \\
\hline Drop out duration & 50 msec Maximum & \\
\hline Transient voltage & $\begin{array}{l} \pm 10 \text { percent Maximum for } \\
250 \mu \mathrm{sec}\end{array}$ & \\
\hline $\begin{array}{l}\text { Electromagnetic } \\
\text { compatibility }\end{array}$ & $\begin{array}{l}\text { Mil-STD-461B including } \\
\text { RE-01 to be amended }\end{array}$ & $\begin{array}{l}\text { Must be adequate for } \\
\text { scientific payloads } \\
\text { (plasma experiments) }\end{array}$ \\
\hline
\end{tabular}


TABLE II. - COMPARISON OF RESISTOJET CONTROL METHODS (ref. 4)

\begin{tabular}{|c|c|c|}
\hline Methods & Advantages & Disadvantages \\
\hline $\begin{array}{l}\text { 1. Constant power and } \\
\text { fixed pressure }\end{array}$ & $\begin{array}{l}\text { Simplest. Can be low power } \\
\text { to be consistent with cabin } \\
\text { air and methane require- } \\
\text { ments }\end{array}$ & Specific impulse degradation \\
\hline $\begin{array}{l}\text { 2. Constant pressure } \\
\text { and variable power }\end{array}$ & $\begin{array}{l}\text { Near optimum specific } \\
\text { impulse for all gas compo- } \\
\text { sitions }\end{array}$ & $\begin{array}{l}\text { Most complicated power } \\
\text { control }\end{array}$ \\
\hline $\begin{array}{l}\text { 3. Constant pressure } \\
\text { and two-power } \\
\text { setting }\end{array}$ & $\begin{array}{l}\text { Higher specific impulse } \\
\text { than method } 1 \text {, Retains } \\
\text { power control simplicity. } \\
\text { Compatible with methane } \\
\text { and air }\end{array}$ & $\begin{array}{l}\text { Specific impulse degradation } \\
\text { for some propellants }\end{array}$ \\
\hline $\begin{array}{l}\text { 4. Constant power and } \\
\text { variable flow } \\
\text { control }\end{array}$ & $\begin{array}{l}\text { Optimum specific impulse } \\
\text { for all gas compositions }\end{array}$ & $\begin{array}{l}\text { Flow control more } \\
\text { complicated than } \\
\text { constant pressure } \\
\text { regulation }\end{array}$ \\
\hline
\end{tabular}

aTentative selection. 
TABLE III. - COMPARISON OF POWER REgULATING METHODS

\begin{tabular}{|c|c|c|}
\hline Methods & Advantages & Disadvantages \\
\hline $\begin{array}{l}\text { Figure } 3(a) \text { single } \\
\text { power setting }\end{array}$ & $\begin{array}{l}\text { Physically simplest - } \\
\text { (one component) } \\
\text { Power factor correction } \\
\text { capacitor is optional }\end{array}$ & $\begin{array}{l}\text { High power efficiency } \\
\text { current limiting transformer } \\
\text { design more difficult than } \\
\text { standard transformer design } \\
\text { Potential disadvantage of } \\
\text { remnant magnetization } \\
\text { Transformer steady-state VA } \\
\text { rating is } \sqrt{2} \text { times maximum } \\
\text { heater power }\end{array}$ \\
\hline $\begin{array}{l}\text { Figure } 3(b) \text { Two } \\
\text { power setting }\end{array}$ & $\begin{array}{l}\text { Bus power not } \\
\text { pulsed }\end{array}$ & $\begin{array}{l}\text { Requires two power } \\
\text { switches }\end{array}$ \\
\hline $\begin{array}{l}\text { Figure } 3(c) \text { Two or } \\
\text { multiple power } \\
\text { settings }\end{array}$ & $\begin{array}{l}\text { Requires only one } \\
\text { power switch }\end{array}$ & $\begin{array}{l}\text { Bus power is pulsed. Pulsing } \\
\text { control circuits are needed }\end{array}$ \\
\hline $\begin{array}{l}\text { Figure } 3(d) \text { Separate } \\
\text { inductor in primary }\end{array}$ & $\begin{array}{l}\text { Potential remnant } \\
\text { magnetization problem } \\
\text { is eased } \\
\text { Transformer steady-state } \\
\text { VA rating about equal to } \\
\text { heater power } \\
\text { Easier to design a high } \\
\text { efficiency transformer }\end{array}$ & $\begin{array}{l}\text { Extra power magnetic component } \\
\text { with attendant power loss and } \\
\text { weight }\end{array}$ \\
\hline $\begin{array}{l}\text { Figure } 3(e) \text { Series } \\
\text { capacitor in } \\
\text { transformer primary }\end{array}$ & $\begin{array}{l}\text { Transformer steady-state } \\
\text { VA rating about equal } \\
\text { to heater power } \\
\text { Can achieve highest } \\
\text { efficiency and lightest } \\
\text { weight }\end{array}$ & $\begin{array}{l}\text { Leading power factor not } \\
\text { easily corrected } \\
\text { Requires at least two } \\
\text { components, while figure } 3(a) \\
\text { needs only one }\end{array}$ \\
\hline $\begin{array}{l}\text { Figure } 3(f) \text { Dual } \\
\text { power regulator } \\
\text { scheme }\end{array}$ & $\begin{array}{l}\text { Maintains bus load power } \\
\text { factor near } 1.0 \text { during } \\
\text { turn on transient as } \\
\text { we } 11 \text { as steady state. } \\
\text { Corrects power factor } \\
\text { and regulates two } \\
\text { thrusters with three } \\
\text { components }\end{array}$ & $\begin{array}{l}\text { Requires simultaneous } \\
\text { operation of two thrusters }\end{array}$ \\
\hline
\end{tabular}


TABLE IV. - BREADBOARD TRANSFORMER DATA

\begin{tabular}{|c|c|}
\hline Item & Description \\
\hline Core & $\begin{array}{l}\text { MC-1717-10 Magnetics Incorporated, core gap faces } \\
\text { lapped and polished }\end{array}$ \\
\hline Primary winding & $\begin{array}{l}66 \text { Turns No. } 18 \text { AWG: } 3 \text { copper heat sink winding } \\
\text { assemblies, each with two } 11 \text { turn, single layer, } \\
\text { pancake windings cemented to each side of a } 0.079 \mathrm{~cm} \\
(0.031 \text { in.) thick, copper plate insulated with a thin } \\
\text { polyimide film. }\end{array}$ \\
\hline Secondary winding & $\begin{array}{l}9 \text { turns: } 4 \text { paralleled No. } 16 \text { Awg windings: } 2 \text { copper } \\
\text { heat sink winding assemblies, each with two } 9 \text { turn } \\
\text { windings constructed the same as the primary winding } \\
\text { assemblies. }\end{array}$ \\
\hline Primary dc resistance & $0.156 \Omega$ at $25{ }^{\circ} \mathrm{C}$ (measured) \\
\hline Secondary dc resistance & $0.0034 \Omega$ at $\left(25^{\circ} \mathrm{C}\right)$ (measured) \\
\hline $\begin{array}{l}\text { Secondary open circuit } \\
\text { inductance }\end{array}$ & $510 \mu H$ (measured) \\
\hline $\begin{array}{l}\text { Leakage inductance } \\
\text { referred to secondary }\end{array}$ & $\begin{array}{l}4.4 \mu \mathrm{H} \text { (measured) Adjustable from } 3.3 \text { to } 8.6 \mu \mathrm{H} \text { by } \\
\text { positioning primary and secondary winding locations. } \\
\text { Centered windings produce } 3.3 \mu \mathrm{H} \text {; primary, and } \\
\text { secondary windings located at opposite ends result in } \\
8.6 \mu \mathrm{H} \text { leakage inductance }\end{array}$ \\
\hline $\begin{array}{l}\text { Maximum flux } \\
\text { density }\end{array}$ & $2.75 \mathrm{kilogauss}$ at $208 \mathrm{~V}$ input, $20 \mathrm{kHz}$ \\
\hline $\begin{array}{l}\text { Core loss } \\
\text { de winding loss }\end{array}$ & $\begin{array}{l}6 \mathrm{~W}, \text { (from manufacturer's data) } \\
5.9 \mathrm{~W} \text { at } 100{ }^{\circ} \mathrm{C}, 26.9 \text { A secondary current }\end{array}$ \\
\hline Measured total loss & $\begin{array}{l}\text { approximately } 24 \mathrm{~W}, 208 \mathrm{~V} \text { input, } 26.9 \mathrm{~A} \text { output, } \\
20 \mathrm{kHz} \text { with a } 1.6 \mathrm{\mu H}, 0.7 \Omega \mathrm{dc} \text { load. }\end{array}$ \\
\hline $\begin{array}{l}\text { ac eddy current } \\
\text { and skin effect } \\
\text { losses }\end{array}$ & $\begin{array}{l}\text { or order } 12 \mathrm{~W} \text { estimated from measured total loss minus } \\
\text { calculated core and dc winding losses }\end{array}$ \\
\hline Power efficiency & $\begin{array}{l}\text { Approximately } 95 \text { percent (measured using power meter, } \\
208 \mathrm{~V} \text { input, } 26.9 \text { A output, } 20 \mathrm{kHz} \text { with a } 1.6 \mu \mathrm{H}, 0.7 \\
\Omega \mathrm{dc} \text { load) }\end{array}$ \\
\hline Temperature Rise & $\begin{array}{l}84{ }^{\circ} \mathrm{C} \text { with natural convection at center of middle } \\
\text { copper heat sink measured with } 208 \mathrm{~V} \text { in, } 27.3 \mathrm{~A} \text { out }\end{array}$ \\
\hline Mass & $0.590 \mathrm{~kg}$ including heat sink clamp \\
\hline
\end{tabular}


TABLE V. - RESISTOJET POWER CONTROLLER TEST DATA

\begin{tabular}{|c|c|c|c|c|c|}
\hline Propellant & $\begin{array}{c}\text { Propellant } \\
\text { pressure, } \\
\mathrm{N} / \mathrm{cm}^{2}\end{array}$ & $\begin{array}{c}\text { Power, } \\
\mathbf{W}\end{array}$ & $\begin{array}{c}\text { Heater } \\
\text { resistance, } \\
\Omega\end{array}$ & $\begin{array}{c}\text { Heater } \\
\text { sheath } \\
\text { temperature, } \\
{ }^{\circ} \mathrm{C}\end{array}$ & $\begin{array}{c}\text { Calculated } \\
\text { power } \\
\text { controller } \\
\text { bus power } \\
\text { factora }\end{array}$ \\
\hline
\end{tabular}

Steady-state data

\begin{tabular}{|l|c|c|c|c|c|}
\hline Argon & $\begin{array}{c}30.8 \\
(44.7 \text { psia })\end{array}$ & 485 & 0.91 & 1020 & $\begin{array}{c}0.980 \\
\text { leading }\end{array}$ \\
Carbon Dioxide & $\begin{array}{c}30.8 \\
(44.7 \text { psia })\end{array}$ & 493 & 0.80 & 820 & $\begin{array}{c}0.998 \\
\text { leading } \\
29.0\end{array}$ \\
$(42.1$ psia $)$
\end{tabular}

At startup

\begin{tabular}{|c|c|c|c|c|c|}
\hline $\begin{array}{c}\text { All } \\
\text { propellants }\end{array}$ & $\begin{array}{c}\text { All } \\
\text { pressures }\end{array}$ & $404^{\mathrm{b}}$ & $0.345^{\mathrm{C}}$ & $25^{\circ} \mathrm{C}$ & $\begin{array}{l}0.766 \\
\text { lagging }\end{array}$ \\
\hline
\end{tabular}

acalculated for $C=0.10 \mu \mathrm{F}, \mathrm{L}=6.0 \mu \mathrm{H}$.

${ }^{b}$ Calculated from measured $d c$ resistance and $L=6.0 \mu \mathrm{H}$.

$c_{d c}$ measurements at transformer connection. 
ORIGINAR PAGGE IS

QE. POOR QUALTY

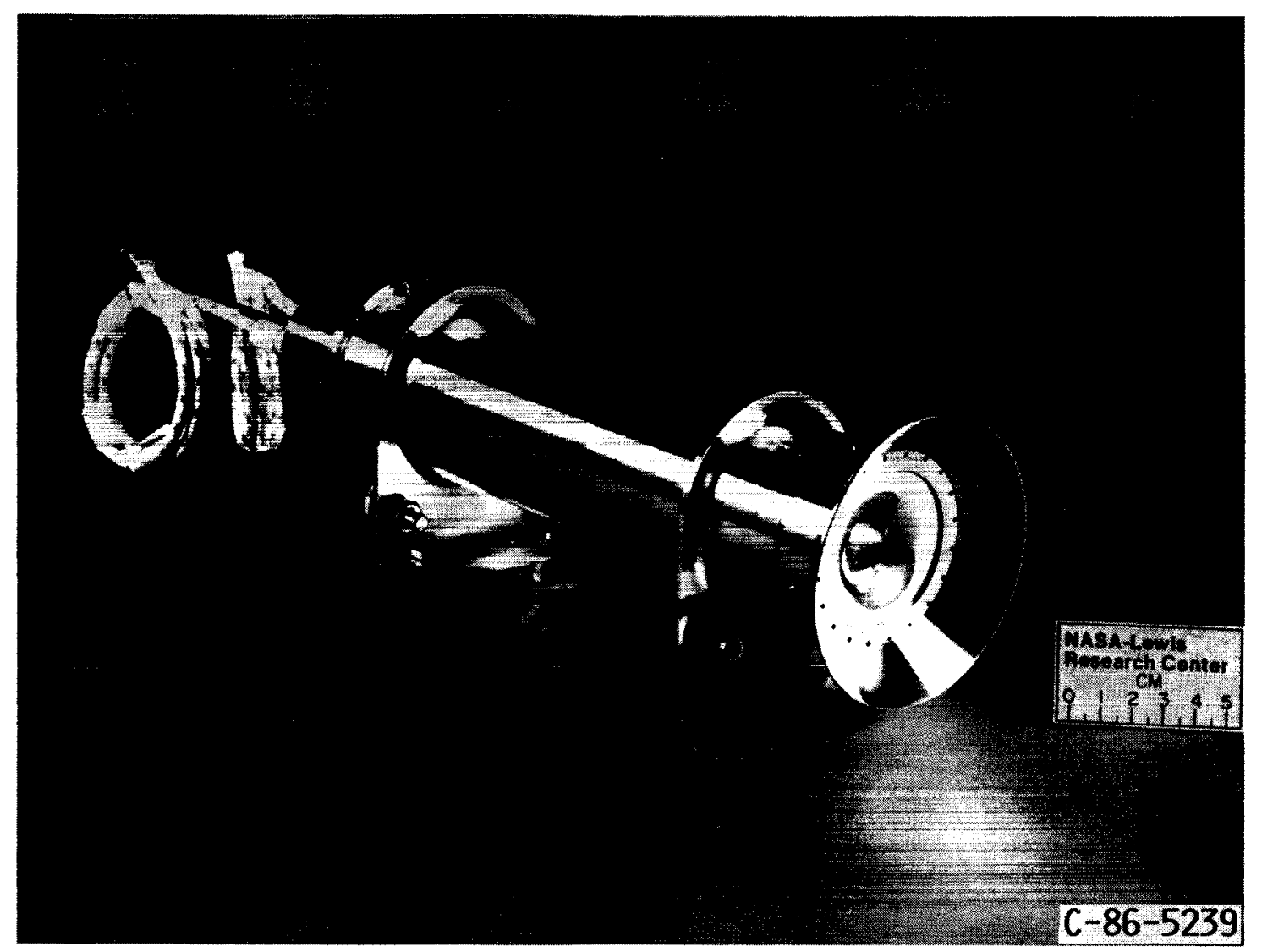

FIGURE 1. - ENGINEERING MODEL OF RESISTOJET. 


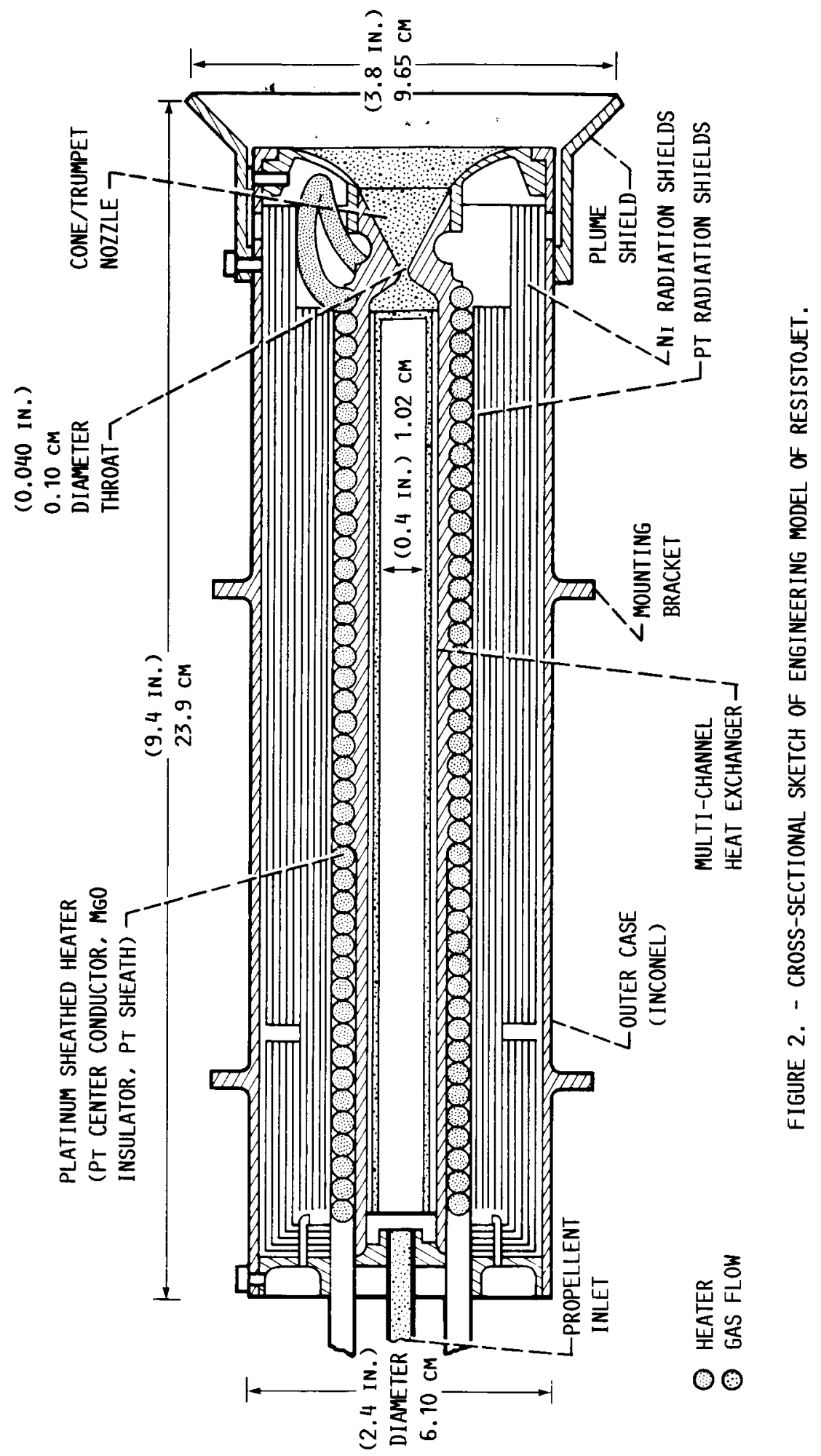




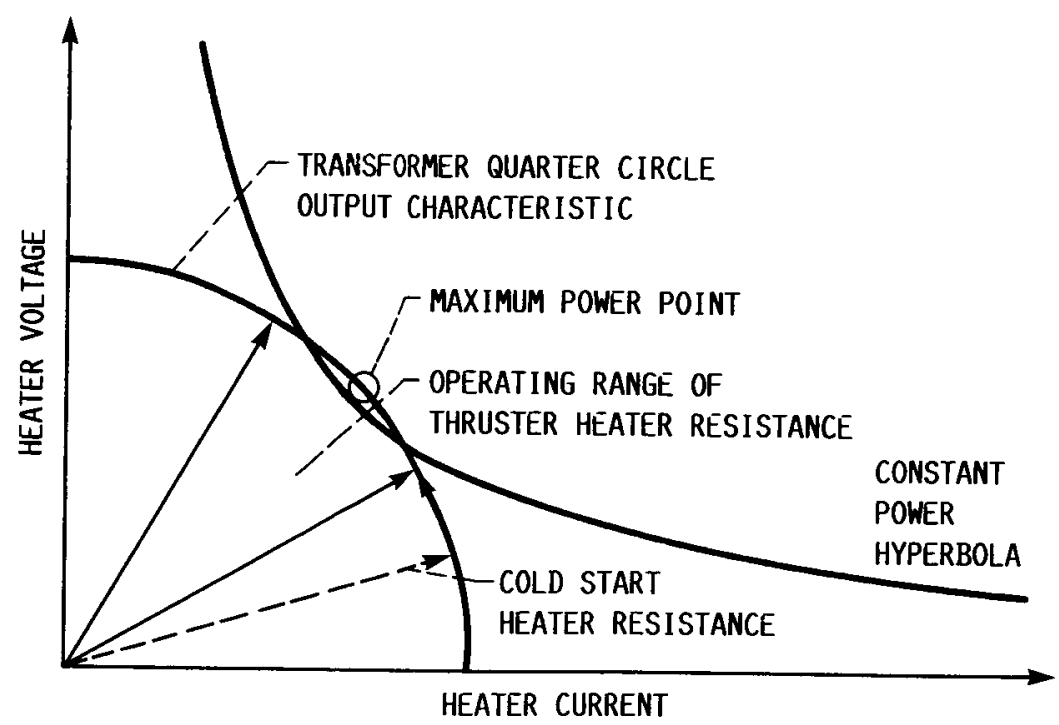

FIGURE 3. - THRUSTER HEATER AND TRANSFORMER OUTPUT CHARACTERISTICS.

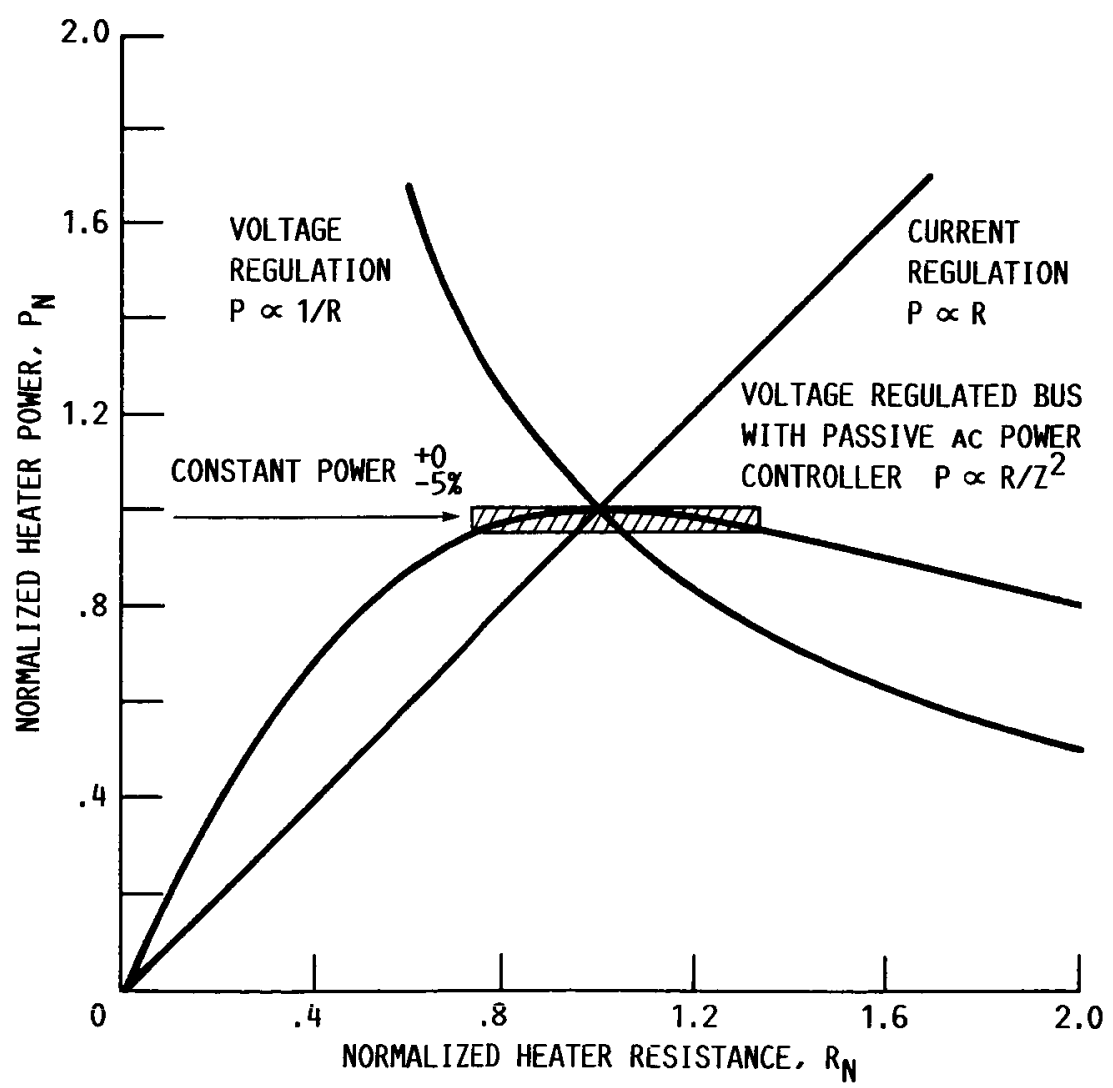

FIGURE 4. - RESISTOJET CALCULATED NORMALIZED POWER VERSUS NORMALIZED HEATER RESISTANCE. 

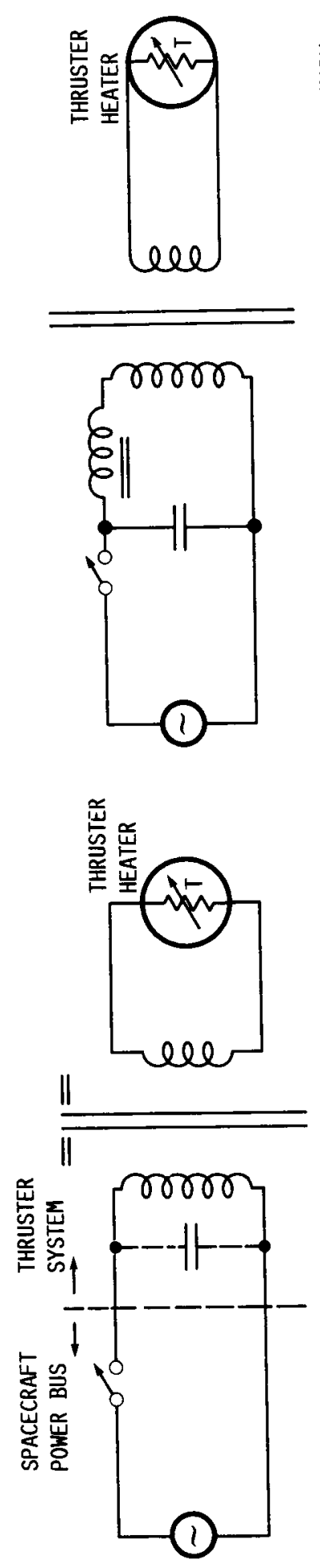
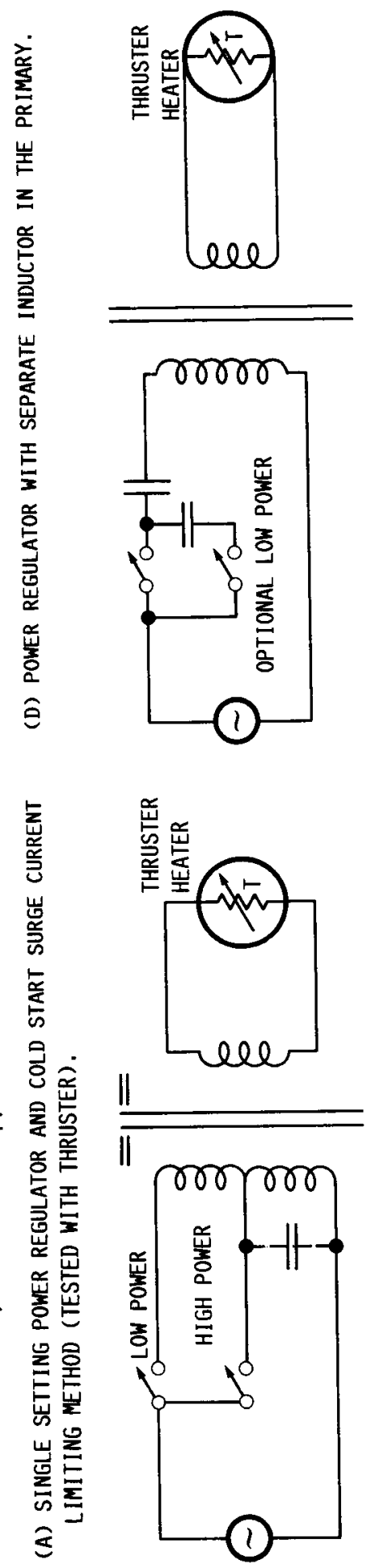
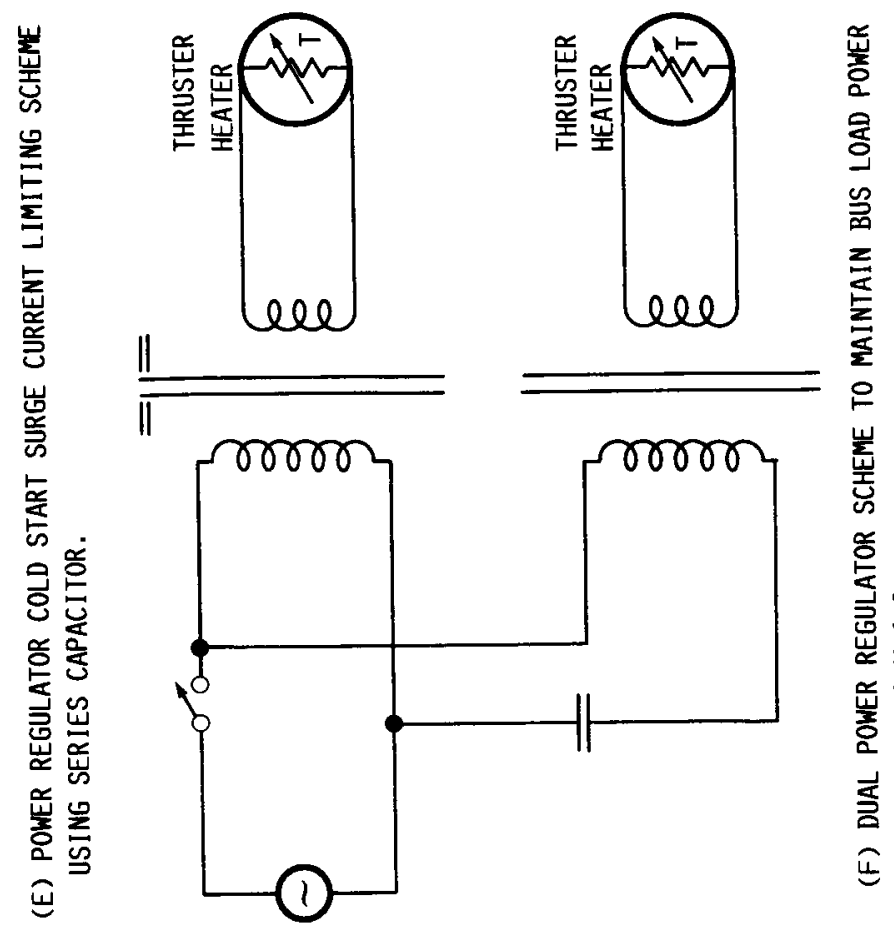

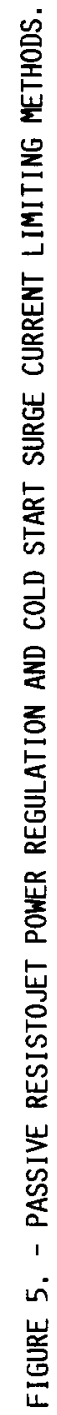

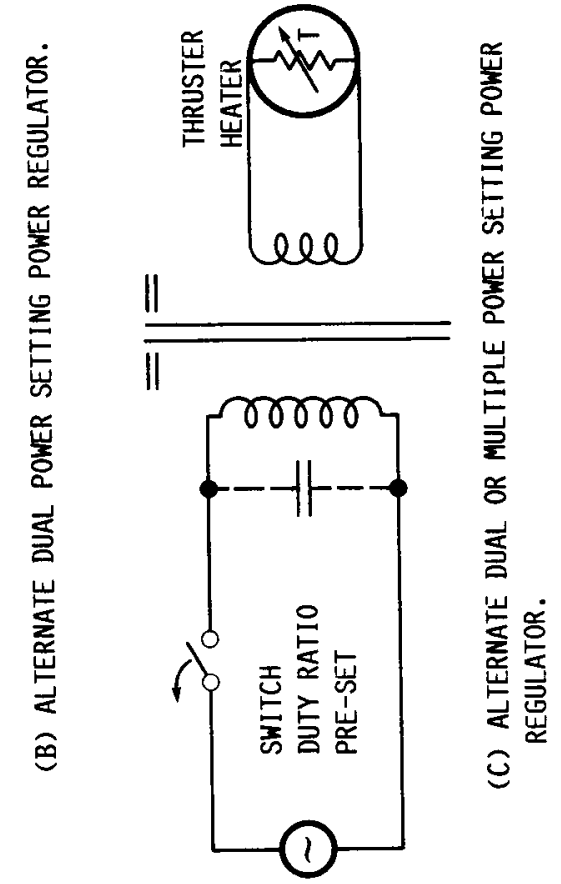




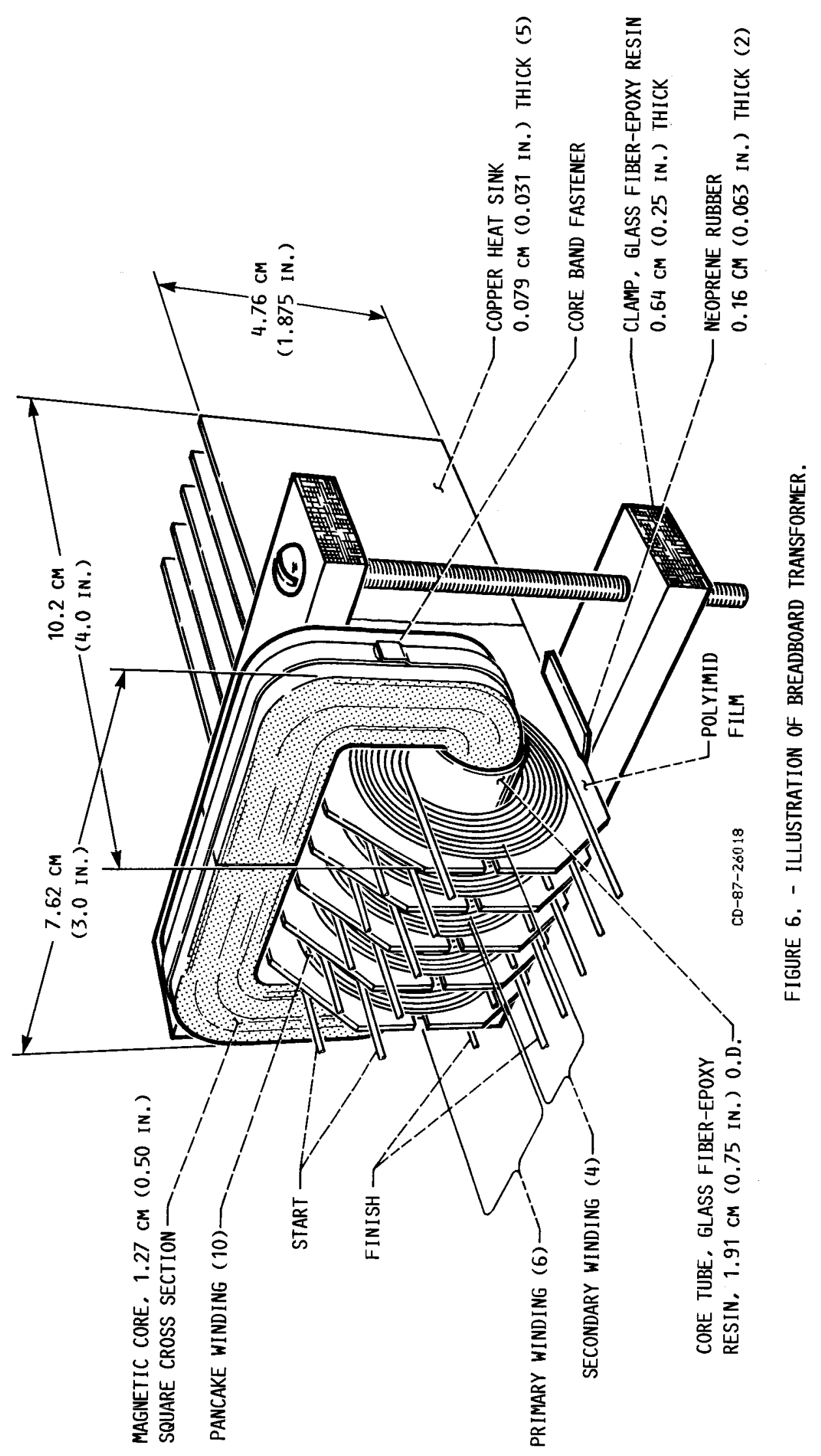




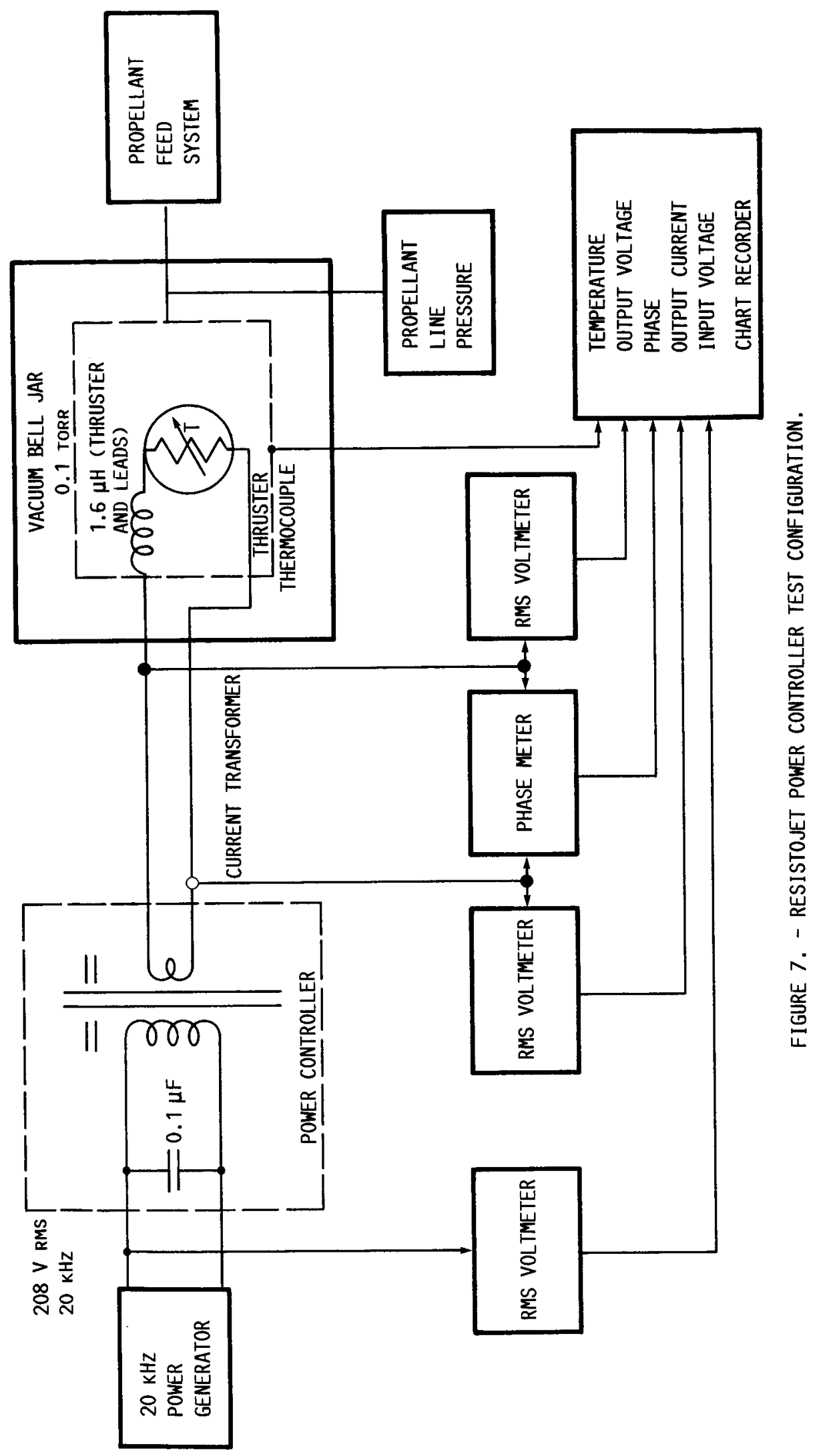



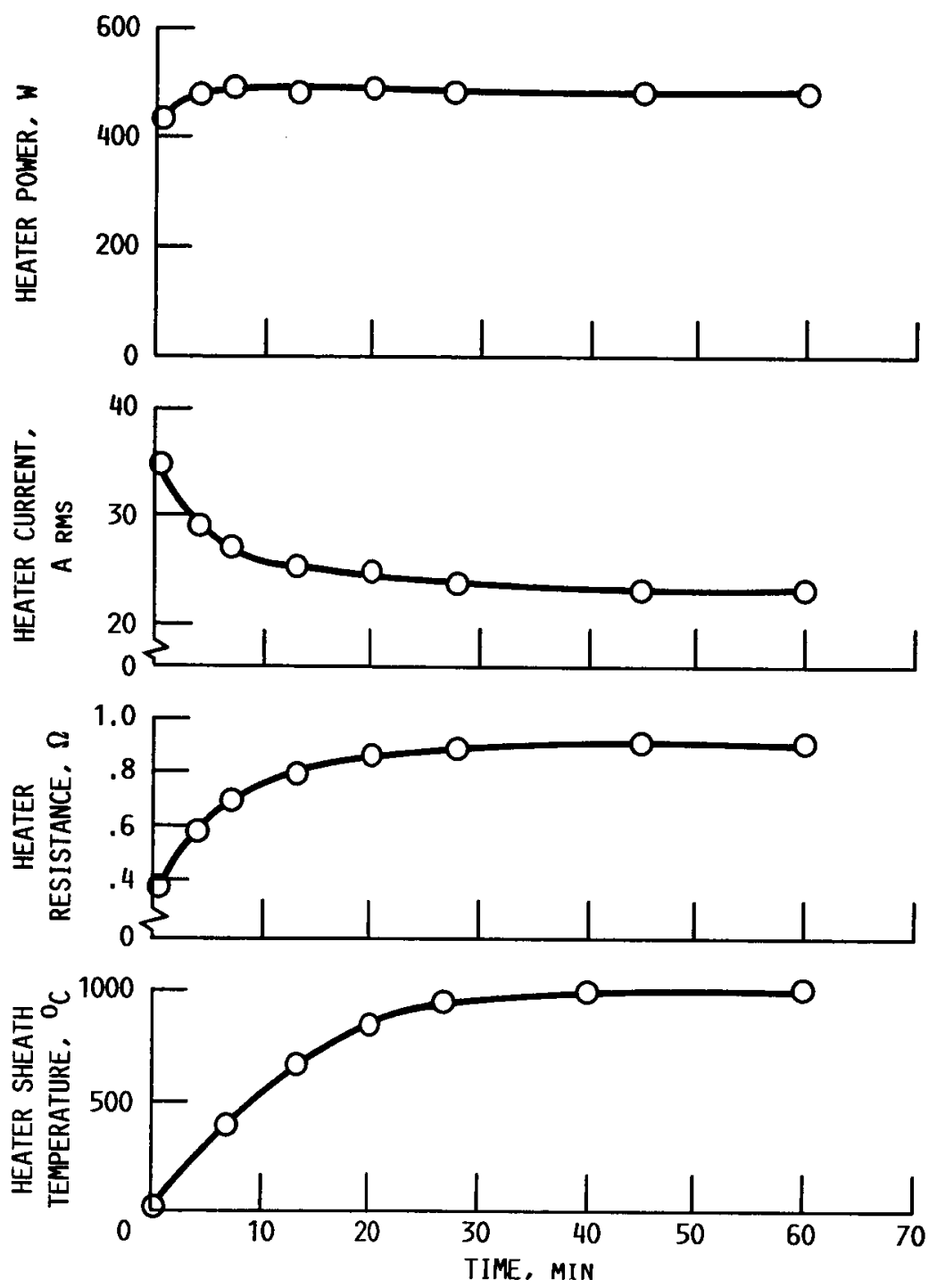

FIGURE 8. - HEATER POWER, CURRENT, RESISTANCE, AND SHEATH TEMPERATURE VERSUS TIME FOR ARGON AT $30.8 \mathrm{~N} / \mathrm{cm}^{2}$ (44.7 PSIA). 

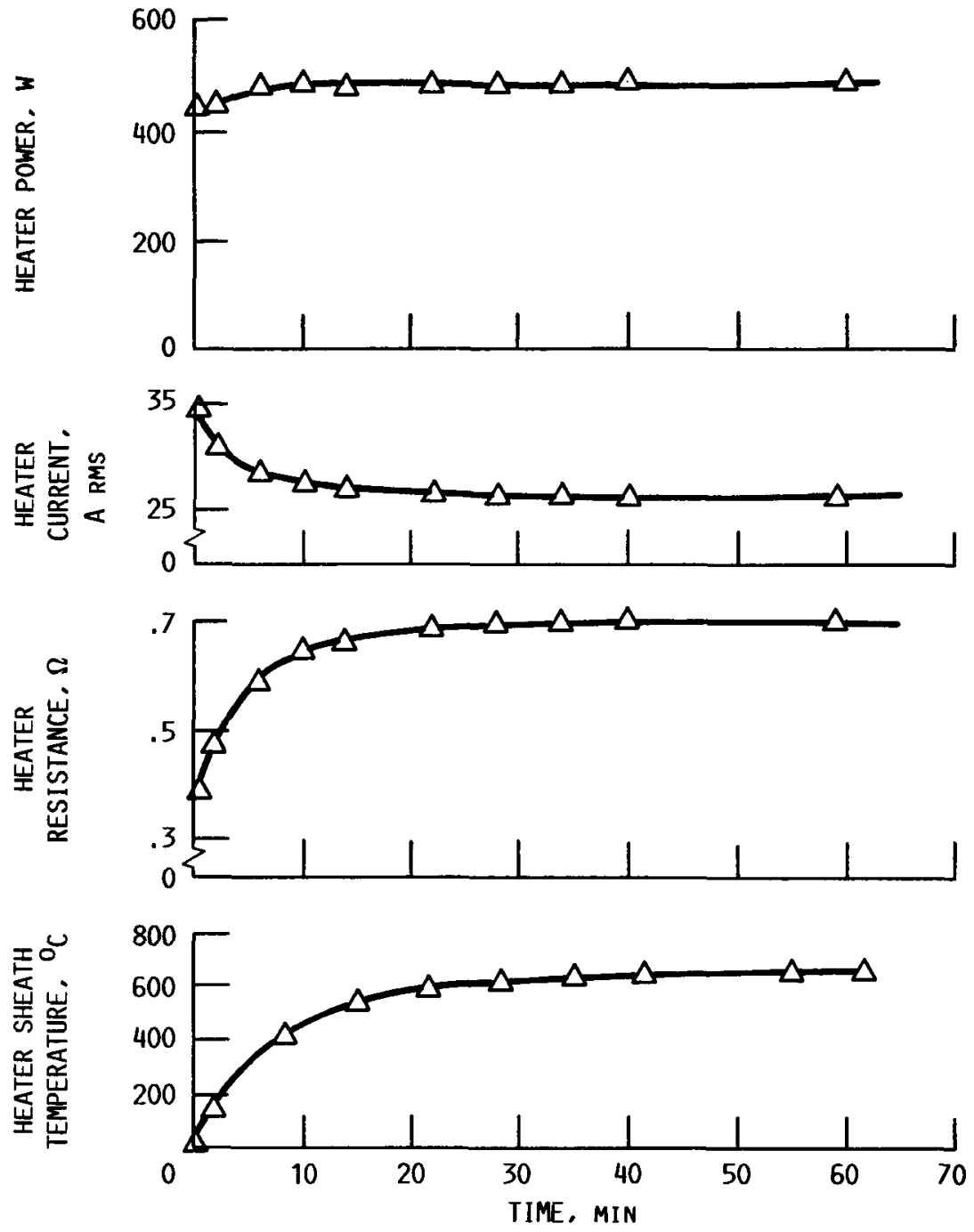

FIGURE 9. - HEATER POWER, CURRENT, RESISTANCE, AND SHEATH TEMPERATURE VERSUS TIME FOR HELIUM AT $29.0 \mathrm{~N} / \mathrm{CM}^{2}$ (42.1 PSIA). 


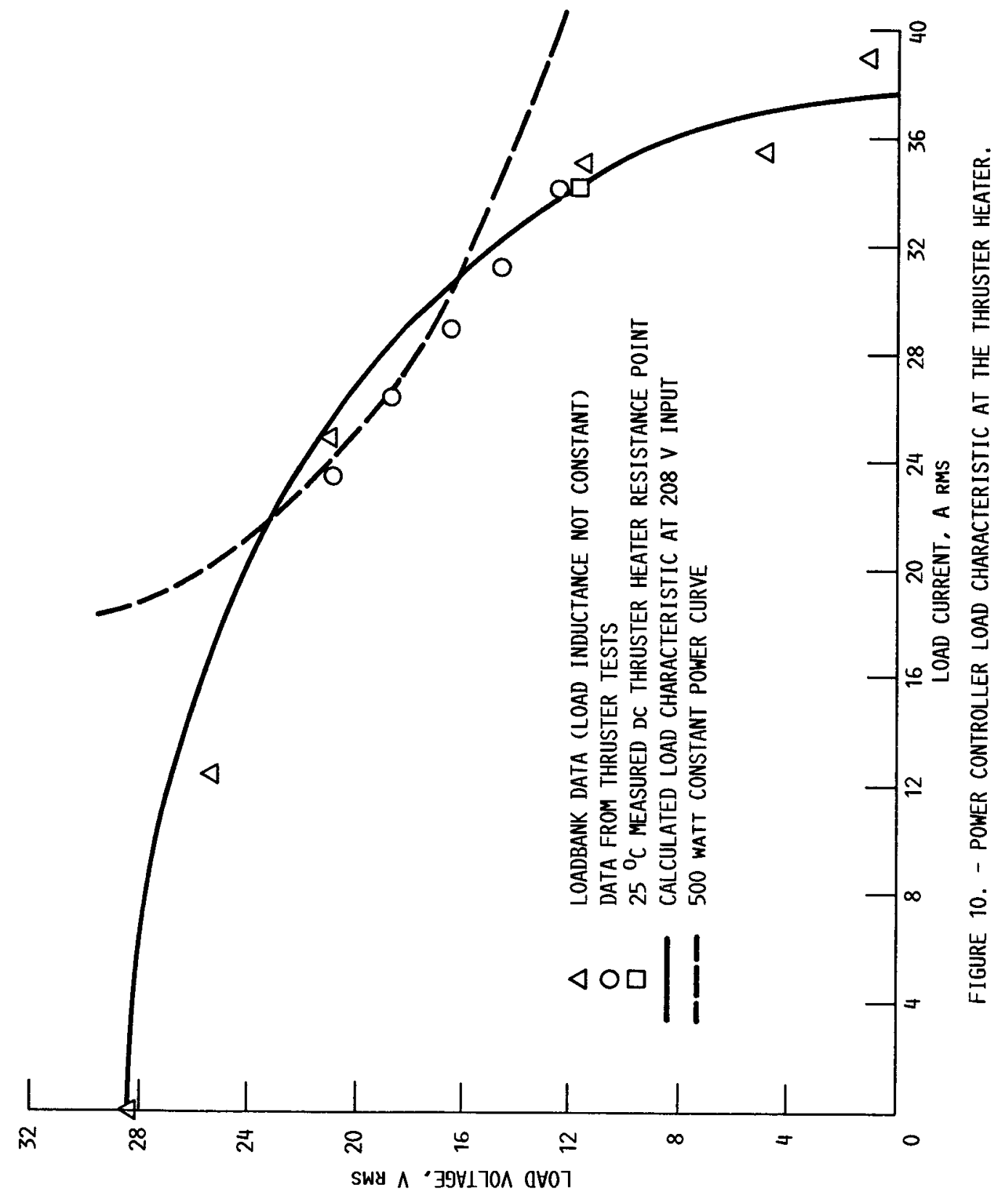




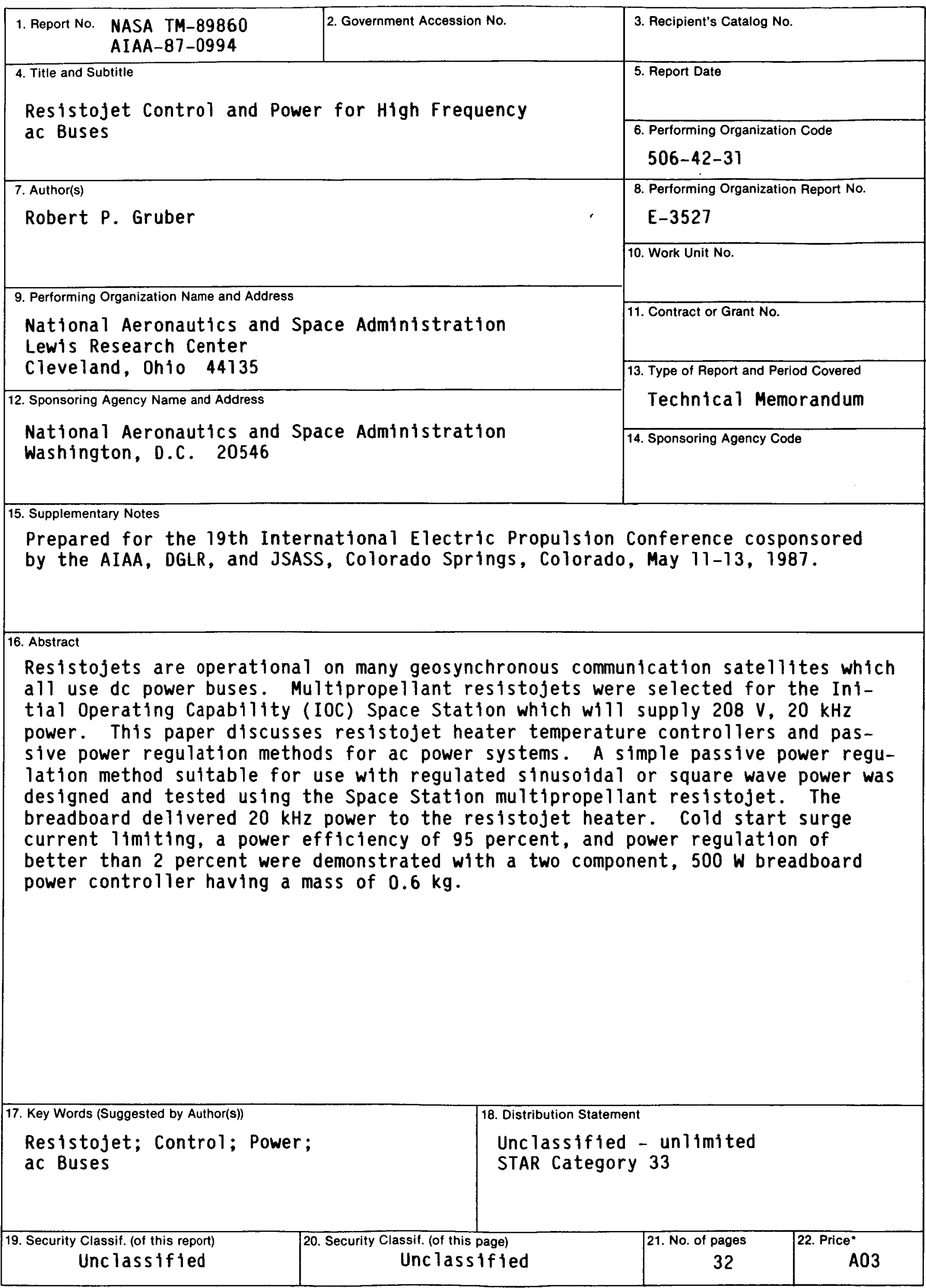

"For sale by the National Technical Information Service, Springfield, Virginia 22161 